\title{
The Relationship Of The Learning Starts Method With A Questions With The Science Learning Outcomes Of Class Iii Region Ii Students In Barebbo District Bone Regency
}

\author{
Muslimin', Muhammad Amran'²,Fahrul Islam ${ }^{3}$ \\ \{muslimin61@yahoo.com ${ }^{1}$, neysaamran@gmail.com ${ }^{2}$, islamfakhrul.2167@gmail.com ${ }^{3}$ \} \\ 1,2,3xPGSD FIP Universitas Negeri Makassar, Indonesia
}

\begin{abstract}
This research is motivated by student learning outcomes that have not been fully said to be good because there are still students who do not achieve mastery grades. The formulation of the problem examined in this study is, How well is the use of the Learning Starts with A Question (LSQ) method in learning science class III in Elementary School Region II, Barebbo District, Bone Regency? Is there a significant relationship between the learning method of Learning Starts with A Question (LSQ) with the learning outcomes of science students in Class III Region II, Barebbo District, Bone Regency? The purpose of this study was to determine the relationship of Learning Starts With A Question (LSQ) learning methods to student learning outcomes in science subjects. The research approach is a quantitative approach. This type of research is correlational research. Research data obtained through questionnaires and documentation. The population in this study were all students of class III Elementary School Region II, District of Barebbo, Bone Regency in the academic year 2018/2019 totaling 110 . The sample in this study amounted to 51 people. The data analysis technique used is descriptive statistical analysis and inferential statistical analysis. The results of the study show that: The use of the Learning Starts with A Questions method for Class III students in Primary Schools II in Barebbo District Bone Regency is in very good category. which is significant between the method of Learning Starts with A Questions and the learning outcomes of third grade students in the Region II Watu Primary School, Barebbo District. The conclusion of the study, that there is a significant relationship between the method of Learning Starts with A Questions with the learning outcomes of science students in grade III Elementary School Region II, Barebbo District, Bone Regency.
\end{abstract}

Keywords: Learning Starts with A Questions Method, Student Learning Outcomes, Science

\section{Introduction}

Education is a conscious effort made by the family, community, and government, through guidance, teaching, and / or training activities, which take place in school and outside of life throughout life to prepare students to be able to play a role in various environments precisely 
in future. According to Government Regulation No. 19 of 2005 article 1 states that: National education standards are the minimum criteria regarding education in the entire territory of the Republic of Indonesia. Meanwhile, according to its function as stipulated in PP No. 19 of 2005 article 3 states that: National education standards serve as a basis in planning, implementing and supervising education in the context of realizing quality education.

Referring to the objectives of primary and secondary education PP No 17 of 2010, in the 2013 curriculum set subjects are grouped into subjects developed nationally (Group A) by the center and subjects developed by the center are complemented by local content developed by the government regions (Group B). The subjects included in group A are Religious Education and Character, Pancasila and Citizenship Education, Indonesian Language, Mathematics, Natural Sciences, and Social Sciences. Subjects included in group B are Arts and Culture and Crafts and Physical Education, Sports and Health. Overall these subjects will produce learning outcomes after the learning process. In the process of walking the learning can not be separated from learning activities.

Evile and Nara (2010) state that, learning is a complex process that contains several aspects. These aspects include: a) an increase in the amount of knowledge, b) the ability to remember and produce, c) the application of knowledge, d) inferring meaning, e) interpreting and linking with reality, whereas learning is a two-way communication, teaching is carried out by the teacher while learning is carried out by students. The learning process takes place abstractly, because it occurs mentally and cannot be observed, it can be known if there are changes in behavior that are different from a person both in cognitive, affective, and psychomotor aspects. Through the learning process, teachers are required to be able to guide and facilitate students so that they can understand the strengths and abilities they have, to further motivate students to be encouraged to learn as best they can to achieve success based on their abilities.

Rifa'i and Anni (2012: 69) state that, "learning outcomes are behavioral changes obtained by students after experiencing learning activities." According to Sudjana (2014: 22), learning outcomes are "abilities possessed by students after receiving experience learning. "Meanwhile according to Winkle (Purwanto 2014: 45), learning outcomes are" changes that cause people to change their attitudes and behavior. "Changes in behavior depend on what students learn at school or at home. From these behavioral changes students can get an assessment of their learning outcomes. According to Minister of Education and Culture Regulation No. 104 of 2014 concerning Learning Outcomes Assessment states that: assessment of learning outcomes by educators is the process of gathering information / evidence about student learning outcomes in spiritual attitude and social attitude competencies, knowledge competencies, and skills competencies carried out planned and systematic during and after the learning process. Assessment of learning outcomes serves to monitor learning progress, learning outcomes, and detect the need for continuous improvement in student learning outcomes. The one factor that can influence the learning outcomes is the learning method.

In general, science is understood as a science that was born and developed through the steps of observation, formulation of problems, preparation of hypotheses, testing hypotheses through experiments, drawing conclusions, as well as the discovery of theories and concepts. Teachers must be able to enter the world of students in the learning process through learning planning. In this case the teacher's ability to enter the world of students is needed both before and during the learning process, so that it can realize successful learning academically because it helps teachers complete learning faster, more attached and more meaningful with satisfying learning outcomes. The teacher teaching method as a tool to achieve the teaching objectives to be achieved, so the better the use of teaching methods the more successful the achievement of 
objectives. Learning Starts with A Questions Method is one of active learning that can provide opportunities for students to be active in learning through asking questions at the beginning of learning [1]. Questions asked by students related to the material to be studied. Students need to read the material first on the material to be studied with the aim that students have initial knowledge on the material to be learned. In addition, the Learning Starts with A Questions method is also a guide for teachers to deliver material so that students do not feel bored with the way the teacher delivers the material being taught.

Based on the results of unstructured observations and interviews conducted with class teachers on April 15, 2019, information was obtained that the Regional School II of Barebbo District, especially the 214 Watu State Primary School and Inpres 3/77 Watu Elementary School often used the Learning starts with A Questions method during the learning process. to train student activity during the learning process. Through the Learning starts with A Questions method students are trained to build their own knowledge. Students are actively involved since the first learning process begins, because before the learning process students first read the material to be taught by the teacher and students make questions, then students ask these questions to their teacher, and also the learning results obtained by students have not been said to be good because there are still students who do not achieve mastery grades.

Based on the above background, the researcher is interested in conducting a correlation study with the title: "The Relationship of the Learning starts with A Questions Method with the Science Learning Outcomes in Class III Elementary School Students Region II In Barebbo District, Bone Regency".

\section{LITERATURE REVIEW}

\section{Learning Starts with A Questions Method}

The method "comprehensive planning in presenting learning material on a regular basis, there is no one contradictory part, and all of them are based on a certain approach [2] ." The more precise the method used by teachers in teaching, is expected to be more effective in achieving learning objectives [3].

The method of learning starts with a question is a method where students are directed to learn by making questions based on the reading given by the teacher [4]. Then students try to find answers to these questions through discussions with other students and the teacher helps if students have difficulty finding answers [5].

Learning Starts With A Question (LSQ) Method is a learning method where the process of learning something new will be more effective if students are active in asking before they get an explanation of the material to be learned from the teacher as a teacher.

Based on some of the opinions above, it can be concluded that the Learning Starts With A Question method is a learning method that stimulates students to ask questions about their subjects. One way to get students to learn actively is to make them ask about subject matter before there is an explanation from the instructor. This method can provide stimulus for students to achieve the key to learning, namely asking.

\section{Student learning outcomes}

Learning outcomes are the culmination of student learning success towards learning goals that have been set, learning outcomes are the result of an interaction of learning outcomes and teaching actions [6]. From the teacher's point of view, the teaching act ends with a process of evaluating learning outcomes [7]. 
learning success is a change that occurs in individuals who learn, not only changes in knowledge, but also knowledge to shape skills, habits, attitudes, understanding, mastery, and appreciation in learning individuals.

From the student's side, the learning outcome is the culmination of the learning process which is evidence of the effort that has been done. Reveals the principles of learning success, namely: 1) changes in learning occur consciously; 2) changes in learning have goals; 3) positive learning changes; 4) changes in learning are continuous; and 5) changes in learning are permanent (lasting) [7].

Based on the above opinion it can be concluded that, what is meant by learning outcomes is the actual achievement stage which is displayed in the form of behavior which includes cognitive, affective and psychomotor aspects and can be seen in the form of habits, attitudes, and rewards. Learning outcomes include cognitive, affective, and psychomotor abilities. Each ability includes: 1) The cognitive domain includes: knowledge (memory), comprehension (understanding, explaining, summarizing), application (applying), analysis (describing, determining relationships), synthesis (organizing, planning,), evaluation (rate). 2) Affective domain consists of: receiving (responding attitude), responding (giving response), valuing (value), organization, characterization (characteristics). Psychomotor domain consists of: includes productive, technical, physical, social and intellectual abilities.

To know indicators of learning success can be seen from the absorption of students and behaviors that appear to students [7].

1)Absorption is the level of mastery of subject matter delivered by the teacher and mastered by students either individually or in groups 2) Change and attainment of behavior as outlined in the basic competencies or indicators of teaching and learning from not knowing to knowing, from not being able to being able to , from incompetent to competent.

\section{Science (Natural Sciences)}

According to H.W Fowler (Trianto, 2015: 9), IPA is "systematic and formulated knowledge, which relates to material symptoms and is based primarily on observation and deduction. Wahyana (Trianto, 2015: 9) said that

Sciences is a collection of knowledge arranged systematically, and in general its use is limited to natural phenomena. Its development is not characterized by a collection of facts, but by the scientific method and scientific attitude.

Sciences is a systematic collection of theories, its application is generally limited to natural phenomena, born and developed through scientific methods such as observation and experimentation and requires scientific attitudes such as curiosity, openness, honesty, and so on.

Prihanto Laksmi (Trianto, 2015: 141), as an educational tool that is useful for achieving educational goals, the science education in schools has certain goals, namely

"1) Provide knowledge to students about the world in which to live and how to behave; 2) Instilling scientific attitude in life; 3) Provide skills to make observations; 4) Educate students to get to know, know how to work and appreciate the discovering scientists; and 5) Using and applying scientific methods in solving problems. "

Learning science specifically as the purpose of education in general as set out in Bloom's taxonomy (Trianto, 2015: 142) that:

It is expected to provide knowledge (cognitive), which is the main goal of learning. The type of knowledge in question is basic knowledge of principles and 
concepts that are useful for daily life. Broadly speaking knowledge of facts that exist in nature to be able to understand and deepen further, and see the information and regularity. Besides that, science learning is also expected to provide skills (psychomotor), scientific attitude ability (affective), understanding, habits and appreciation. In searching for answers to a problem. Because these characteristics are different from other learning.

Based on Bloom's taxonomy, it is increasingly clear that science teaching and learning processes are more emphasized on the process skills approach, so students can find facts, build concepts, theories and scientific attitudes of students themselves which ultimately can positively influence the quality of the process education and educational products.

\section{Methods}

This study uses a quantitative approach to the type of correlational research. The population is 110 people consisting of all third grade students in Elementary School area II, Barebbo District, Bone Regency. The sample in this study included 51 people obtained from Class III students at SDN 214 Watu and SD Inpres 3/77 Watu. The sampling technique uses purposive sampling which is the technique of determining the sample where the researcher determines the sampling by setting specific characteristics in accordance with the purpose of the study so that it is expected to answer the research problem. The data collection technique used is a questionnaire.

\section{a. Descriptive Statistical Analysis}

Descriptive statistical analysis is used to calculate data in the form of frequency distribution tables, averages and percentages of each variable to be further categorized in the category tables for each variable. The description of the state of the school environment is categorized in the following table.

Table 2.1. Percentage Criteria Table for Respondents' Responses

\begin{tabular}{cl}
\hline Percentage Score & Category \\
\hline $84,01 \%-100 \%$ & Very Good \\
\hline $68,01 \%-84,00 \%$ & Good \\
\hline $52,01 \%-68,00 \%$ & Quite Good \\
\hline $36,01 \%-52,00 \%$ & Less Good \\
\hline $20,00 \%-36,00 \%$ & Not Good \\
\hline
\end{tabular}

Source: Hidayatullah Journal The level of student learning outcomes is categorized as follows.

Table 2.2 . Learning Outcomes Criteria Table

\begin{tabular}{crc}
\hline No & Value Range & Category \\
\hline 1 & $\geq 80 \%$ & Very High \\
\hline 2 & $60 \%-79 \%$ & High \\
\hline 3 & $40 \%-59 \%$ & Medium \\
\hline
\end{tabular}




\begin{tabular}{crc}
\hline 4 & $20 \%-39 \%$ & Low \\
\hline 5 & $<20 \%$ & Very Low
\end{tabular}

\section{b. Inferential Statistical Analysis}

Inferential statistical analysis is used to see the relationship between variables $\mathrm{X}$ and $\mathrm{Y}$. In this study what will be analyzed inferential is the steatistic hypothesis as follows:

$\mathrm{H}_{0}=\rho=0$ : There is no significant relationship between the Learning Starts with A

Questions Method with the Science Learning Outcomes of Class III Elementary School Barebbo District Bone Regency

$\mathrm{H}_{1}=\rho \neq 0$ : There is a significant relationship between the Learning Starts with A

Questions Method with the Science Learning Outcomes of Class III

Students in Elementary Schools Region II, Barebbo District, Bone Regency.

To do the analysis the following formulas are used:

a. Person Product Moment Correlation

Information :

$$
\mathrm{r}_{\mathrm{xy}}=\frac{N \sum X Y-\left(\sum X\right) \cdot\left(\sum Y\right)}{\sqrt{\left\{N \sum X^{2}-\left(\sum X\right)^{2}\right\} \cdot\left\{N \cdot \sum Y^{2}-\left(\sum Y\right)^{2}\right\}}}
$$

$\mathrm{r}=$ correlation coefficient

$\mathrm{X}=$ School environment variable

$\mathrm{Y}=$ Learning motivation variable

$\mathrm{N}=$ Number of respondents

Furthermore, to see how big the relationship between variable X (school environment) and $\mathrm{Y}$ variable (learning motivation), the Consultation Correlation Coefficient Interpretation table follows.

Table 2.3 Correlation Coefficient Interpretation Table

\begin{tabular}{cc}
\hline Coefficient Intervals & Relationship Level \\
\hline $0,80-1,000$ & Very Strong \\
\hline $0,60-0,799$ & Strong \\
\hline $0,40-0,599$ & Medium \\
\hline $0,20-0,399$ & Low \\
\hline $0,00-0,199$ & Very Low \\
\hline
\end{tabular}

Source: Sugiyono (2016: 184)

b. Determination formula

Furthermore, to determine the degree of contribution of the Learning Starts with A Questions Method with the learning outcomes of Class II students at Elementary School Region II,

Barebbo District, Bone Regency, namely by using the formula of determination as follows [8]. $\mathrm{KP}=\mathrm{r} 2 \times 100 \%$

Information:

$\mathrm{KP}=$ The magnitude of the determinant coefficient (determinant)

$r=$ Correlation Coefficient 
c. T-test

For testing significant correlations, the t-calculation formula is used as follows: [8]

Information:

$$
\mathrm{T}_{\text {count }}=\frac{r \sqrt{n-2}}{\sqrt{1-r^{2}}}
$$

$\mathrm{r}=$ calculated value

$\mathrm{n}=$ Number of respondents

After testing the $\mathrm{t}$-count, then the next is testing the hypothesis with the testing rules namely:

1. If $\mathrm{t}$-count $\geq$ table then $\mathrm{H} 1$ is accepted and $\mathrm{H} 0$ is rejected.

2. If $\mathrm{t}$-count $\leq$ table then $\mathrm{H} 1$ is rejected and $\mathrm{H} 0$ is accepted.

\section{Discussion}

This research was conducted at SDN 214 Watu and SD Inpres 3/77 Watu Barebbo District Bone Regency on the days of April 23 - June 23, 2019. This study was conducted to determine the relationship between the Learning Starts with A Questions Method with the science learning outcomes of third grade students by giving questionnaire to students. The data obtained and analyzed were scores obtained from the Learning Starts with A Questions and data on the daily learning outcomes / tests of students of class III of SDN 214 Watu and SD Inpres 3/77 Watu of Barebbo District of Bone Regency.

\subsection{Research Result}

\section{Descriptive Statistics Analysis}

a. Using the Learning Starts Method with A Questions SDN 214 Watu and SD Inpres 3/77 Watu Barebbo District Bone Regency

Based on data from the questionnaire about the method of Learning Starts with A Questions SDN 214 Watu and SD Inpres 3/77 Watu Barebbo District Bone Regency which has been distributed to 51 respondents consisting of 25 statements, obtained the highest score of 99 and the lowest score of 65 indicates the average of $81.90 \%$ and percentage of $82.05 \%$ After consultation on the percentage criteria of respondents' responses, it was found that the Learning Starts with A Questions Score SDN 214 Watu and SD Inpres 3/77 Watu Barebbo District Bone Regency were in good category .

b. Level of Motivation for Studying High Grade Students of SDN 11 Watampone, Tanete Riattang District, Bone Regency

Data about the science learning outcomes of third grade students of SDN 214 Watu and SD Inpres 3/77 Watu Barebbo District Bone Regency obtained through documentation of the daily science test scores achieved by respondents can be seen in the list of science learning outcomes in Annex 7 page 81. The data shows the highest score is 100 and the lowest score is 30 , and shows an average of $79.17 \%$ and a percentage of $79 \%$ after consultation on the interpretation guidelines that have been set in, it is found that the results of science learning of third grade students of SDN 214 Watu and SD Inpres 3/77 Watu Barebbo District Bone Regency is in the high category. 


\section{Inferential Statistical Analysis}

\section{a. Person Product Moment Correlation}

Person Product Moment correlation test results obtained a value of 0.55 , then consulted into the interpretation coefficient interpretation table is at a moderate level of relationship. b. Determination formula

After using the formula of determination, the degree of relationship obtained between the method of Learning Starts with A Questions and the learning outcomes of third grade students in Elementary School Region II, Barebbo District, Bone Regency is $30.25 \%$.

c. T-test

After doing the t-test, the value of t-count is 4.609869 and t-table is 2.00985. It turns out that t-hitung $\geq \mathrm{t}$-tabel, so $\mathrm{H} 1$ is accepted and $\mathrm{H} 0$ is rejected. This means that there is a significant relationship between the Learning Starts with A Questions method with the learning outcomes of Grade III students in Primary Schools Region II, Barebbo District, Bone Regency.

\section{Discussion}

Based on these results it can be concluded that there is a significant relationship between the Learning Starts with A Questions method with the learning outcomes of third grade students of SDN 214 Watu and SD Inpres 3/77 Watu Barebbo District Bone Regency. This means that the better the students' perceptions of the Learning Starts with A Questions method, the more students will have high learning outcomes. This is in accordance with the literature review and thinking framework in this study, where one of the ways to make students learn actively is to make them ask about the subject matter before there is an explanation from the instructor to achieve the key to learning that is asking to improve student learning outcomes.

\section{Conclusions}

Based on the results of research and discussion, the conclusions of the researcher can be put forward as follows.

1. The use of the Learning Starts with A Questions method for Grade III students in Primary Schools II in Barebbo District, Bone Regency is in the good category.

2. Science learning outcomes of third grade students of Elementary School Region II, Barebbo District, Bone Regency are in the high category.

3. That there is a significant relationship between the Learning Starts with A Questions method with the learning outcomes of class III students in area II, Barebbo District, Bone Regency.

\section{References}

[1] D. N. Haryadi dan S. Nurhayati, "Penerapan Model Learning Start With A Question Berpendekatan ICARE pada Hasil Belajar," Jurnal Inovasi Pendidikan Kimia, vol. 9, no. 2, 2015.

[2] Sudajana, Metode Statistika. Bandung: Tarsito, 2005.

[3] Fathurrohman, M. Sobry Sutikno, dan Pupuh, Strategi Belajar Mengajar. Melalui Penanaman Konsep Umum dan Konsep Islami. Bandung: Refika Aditama, 2010. 
[4] M. AFANDI dan I. NURJANAH, "PENGARUH METODE PEMBELAJARAN LEARNING START WITH A QUESTION (LSQ) TERHADAP HASIL BELAJAR IPS KELAS IV MIN 2 BANDAR LAMPUNG TAHUN PELAJARAN 2017/2018," Terampil: Jurnal Pendidikan dan Pembelajaran Dasar, vol. 5, no. 1, hlm. 43-58, 2018.

[5] Hamruni, Strategi dan Model-Model Pembelajaran Aktif enyenangkan. Yogyakarta: UIN Sunan Kalijaga., 2009.

[6] Z. Zukira, A. H. Harun, dan J. Jamaludin, "Meningkatkan Hasil Belajar Siswa Kelas III Sekolah Dasar Alkhairaat Towera Melalui Model Pembelajaran Kooperatif Tipe Number Head Together (NHT) Pada Mata Pelajaran PKn,” Jurnal Kreatif Online, vol. 3, no. 4.

[7] Supardi, Penilaian Autentik Pembelajaran Afektif, Kognitif, dan Psikomotor Konsep dan Aplikasi. Jakarta: Raja Grafindo Persada, 2015.

[8] Riduwan, Dasar-Dasar Statistika. Bandung: Alfabeta, 2016.

[9] Afandi, Muhammad dan Isnaini Nurjanah. Pengaruh Metode Pembelajaran LSQterhadap Hasil Belajar IPS Kelas IV MIN 2 Bandar Lampung Tahun Pelajaran 2017/2018. Jurnal Pendidikan dan Pembelajaran Dasar: (Online). Vol. 5. No.1. 2018.

[10] Amirul, Fatkhan Huda. Pengertian Metode Pembelajaran LSQ. (Online). 2017.

[11] Arikunto, Suharsimi. Manajemen Penelitian. Jakarta: Rineka Cipta. 2010.

[12] Arikunto, Suharsimi, Prosedur Penelitian Suatu Pendekatan Praktik. Jakarta: Rineka Cipta. 2011.

[13] Dahar, Ratna Wilis, Teori-teori Belajar Dan Pembelajaran. Jakarta: Erlangga, 2011.

[14] Emzir, Metodologi Penelitian Pendidikan Kuantitatif \& Kualitatif. Depok: Raja Grafindo Persada, 2017.

[15] Hamalik, Oemar, Proses Belajar Mengajar. Jakarta: Bumi Aksara, 2010.

[16] Khodijah, Nyanyu, Psikologi Pendidikan. Jakarta: Raja Grafindo Persada, 2017.

[17] Nidawati,.Belajar Dalam Perspektif Psikologi dan Agama, (Online), Vol. 1. No. 1. (Diakses 15 juni 2019), 2013.

[18] Purnama, Nilma, Pengaruh Strategi Pembelajaran Aktif Metode Memulai Pembelajaran dengan Pertanyaan (Learning Starts with a Questions) terhadap Hasil Belajar Matematika Siswa. 2010.

[19] Sapriati, Amalia. Dkk. Pembelajaran IPA di SD. Jakarta: Universitas Terbuka, 2009.

[20] Sugiyono, Metode Penelitian Pendidikan, Pendekatan Kuantitatif, Kualitatif, dan R\&D. Bandung: Alfabeta, 2017.

[21] Sumantri Mohammad Syarif, Strategi Pembelajaran. Jakarta: Raja Grafindo Persada. 2015

[22] Sumatowa, Usman, Pembelajaran IPA di Sekolah Dasar. Jakarta: Indeks, 2011.

[23] Supardi Penilaian Autentik Pembelajaran Afektif, Kognitif, dan Psikomotor Konsep dan Aplikasi. Jakarta: Raja Grafindo Persada, 2015.

[24] Jono Agus, Cooperative Learning TEORI \& APLIKASI PAIKEM. Surabaya: Pustaka Pelajar, 2014.

[25] Suryabrata Sumadi, Metodologi Penelitian. Jakarta: Raja Grafindo Persada, 2011.

[26] Wahab Rohmalina, Psikologi Belajar. Jakarta: Raja Grafindo Persada, 2016.

[27] Wisudawati Asih Widi, dkk, Metodologi Pembelajaran IPA. Jakarta: Bumi Aksara, 2017. 
